\title{
Halomonas sabkhae sp. nov., a moderately halophilic bacterium isolated from an Algerian sabkha
}

Correspondence

Mercedes Monteoliva-Sánchez mmonteol@ugr.es

\author{
K. Kharroub, ${ }^{1,2}$ M. L. Jiménez-Pranteda, ${ }^{1}$ M. Aguilera, ${ }_{1}^{1}$ A. Boulahrouf ${ }^{3}$ \\ A. Ramos-Cormenzana ${ }^{1}$ and M. Monteoliva-Sánchez ${ }^{1}$
}

\author{
${ }^{1}$ Departamento de Microbiología, Facultad de Farmacia, Campus Universitario de Cartuja s/n \\ 18071, Granada, Spain \\ ${ }^{2}$ Institut de Nutrition de l'Alimentation et des Technologies Agro-Alimentaires, Faculté des Sciences \\ de la Nature et de la Vie, Université Mentouri, Constantine, Algeria \\ ${ }^{3}$ Département des Sciences de la Nature et de la Vie, Faculté des Sciences de la Nature et de la \\ Vie, Université Mentouri, Constantine, Algeria
}

\begin{abstract}
A novel moderately halophilic bacterium belonging to the genus Halomonas was isolated from brine samples collected from Ezzemoul sabkha in north-eastern Algeria. The cells of strain 5-3 ${ }^{\top}$ were Gram-negative, rod-shaped and non-motile. The strain was catalase- and oxidase-positive and produced an exopolysaccharide. Growth occurred at $\mathrm{NaCl}$ concentrations of 5-25\% (optimum at $7.5 \%$ ), at $30-50{ }^{\circ} \mathrm{C}$ (optimum at $37-40{ }^{\circ} \mathrm{C}$ ) and at $\mathrm{pH} 6.0-9.0$ (optimum at $\mathrm{pH}$ 7.5). The major fatty acids were $\mathrm{C}_{12: 0} 3-\mathrm{OH}, \mathrm{C}_{16: 1} \omega 7 c /$ iso- $_{15: 0} 2-\mathrm{OH}, \mathrm{C}_{16: 0}, \mathrm{C}_{18: 1} \omega 7 \mathrm{c}$ and $\mathrm{C}_{19: 0} \omega 8 \mathrm{c}$ cyclo. The $\mathrm{G}+\mathrm{C}$ content of the genomic DNA was $57.0 \mathrm{~mol} \%\left(T_{\mathrm{m}}\right)$. The affiliation of strain $5-3^{\top}$ with the genus Halomonas was confirmed by $16 \mathrm{~S}$ rRNA gene sequence comparisons. The most closely related species was Halomonas halmophila, which showed a $16 \mathrm{~S}$ rRNA gene sequence similarity of $99.7 \%$. However, the level of DNA-DNA relatedness between the novel isolate and the related Halomonas species was less than $31.4 \%$. On the basis of the data from this polyphasic study, strain $5-3^{T}$ represents a novel species of the genus Halomonas, for which the name Halomonas sabkhae sp. nov. is proposed. The type strain is $5-3^{\top}$ $\left(=\right.$ CECT $7246^{\top}=$ DSM $19122^{\top}=$ LMG $\left.24084^{\top}\right)$.
\end{abstract}

On the basis of phylogenetic analyses, the family Halomonadaceae (Dobson \& Franzmann, 1996; Franzmann et al., 1988) contains the genera Halomonas (the type genus) (Vreeland et al., 1980), Carnimonas (Garriga et al., 1998), Chromohalobacter (Ventosa et al., 1989), Cobetia (Arahal et al., 2002a) and Zymobacter (Okamoto et al., 1993). Species of the genus Halomonas have been isolated from a wide variety of hypersaline environments, including salt lakes (Great Salt Lake, Antarctic lakes), soda lakes, saline soils, salterns, deep-sea environments and hydrothermal vent habitats (Dobson \& Franzmann, 1996; Fendrich, 1988; Franzmann et al., 1987; Kaye et al., 2004; MartinezCánovas et al., 2004; Poli et al., 2007; Quillaguamán et al., 2004; Reddy et al., 2003; Vreeland et al., 1980). In this study, a novel exopolysaccharide-producing

The GenBank/EMBL/DDBJ accession number for the 16S rRNA gene sequence of strain $5-3^{\top}$ is EF442769.

A maximum-parsimony phylogenetic tree, based on $16 \mathrm{~S}$ rRNA gene sequences, for strain $5-3^{\top}$, species of the genus Halomonas and other taxa comprising Gram-negative, halophilic bacteria is available with the online version of this paper. strain was isolated and characterized, and can be classified as a novel species of the genus Halomonas.

Strain $5-3^{\mathrm{T}}$ was isolated from brine samples collected from Ezzemoul sabkha in north-eastern Algeria. The novel strain was isolated using a halophilic medium (Oren et al., 1995) with the following composition $\left(\mathrm{l}^{-1}\right.$ distilled water): $125 \mathrm{~g}$ $\mathrm{NaCl}, 160 \mathrm{~g} \mathrm{MgCl}_{2} \cdot 6 \mathrm{H}_{2} \mathrm{O}, 5 \mathrm{~g} \mathrm{~K}_{2} \mathrm{SO}_{4}, 0.1 \mathrm{~g} \mathrm{CaCl}_{2} \cdot 2 \mathrm{H}_{2} \mathrm{O}$, $1 \mathrm{~g}$ yeast extract, $1 \mathrm{~g}$ Casamino acids and $2 \mathrm{~g}$ soluble starch. The $\mathrm{pH}$ of the medium was adjusted to 7.0 with $\mathrm{NaOH}$ and the incubation temperature was $37^{\circ} \mathrm{C}$.

The medium used for the growth and characterization of strain $5-3^{\mathrm{T}}$ had the following composition $\left(1^{-1}\right.$ distilled water): $5 \mathrm{~g}$ yeast extract, $5 \mathrm{~g}$ proteose peptone no. 3 (Difco) and $1 \mathrm{~g}$ glucose, supplemented with a $7.5 \%(\mathrm{w} / \mathrm{v})$ sea-salt solution (Rodriguez-Valera et al., 1981; Subov, 1931). Cellular morphology was determined as described previously (Kharroub et al., 2006). Gram staining was performed by using samples fixed with acetic acid, as described by Dussault (1955). NaCl tolerance was determined in growth medium prepared with $0,3,5,7.5,10,15$, 20,25 or $30 \%(\mathrm{w} / \mathrm{v}) \mathrm{NaCl}$. The $\mathrm{pH}$ range for growth was 
tested from $\mathrm{pH} 5.0$ to $\mathrm{pH}$ 10.0. The growth temperatures tested included 4, 22, 30, 37, 40, 50, 55 and $60{ }^{\circ} \mathrm{C}$. Nitrate respiration was tested as outlined by Mata et al. (2002). Nitrate reduction was tested using the sulfanilic acid and $\alpha$ naphthylamine method (Smibert \& Krieg, 1981). Tests for the formation of indole and the hydrolysis of aesculin, gelatin, starch, Tween 20 and Tween 80 were performed as described by Kharroub et al. (2006). Growth on MacConkey agar supplemented with a $7.5 \%(\mathrm{w} / \mathrm{v})$ seasalt solution was assessed. Tyrosine hydrolysis was determined by checking for clear zones on a solid medium (Mata et al., 2002) supplemented with $5 \mathrm{~g}$ tyrosine $1^{-1}$; pigment production was also tested using this medium. The Voges-Proskauer, ONPG and methyl red tests and tests for urea hydrolysis, lysine decarboxylase and ornithine decarboxylase were performed according to the procedures of Larpent \& Larpent-Gourgaud (1985), using supplementation with a $7.5 \%(\mathrm{w} / \mathrm{v})$ sea-salt solution. Catalase production was tested using $10 \%(\mathrm{v} / \mathrm{v}) \mathrm{H}_{2} \mathrm{O}_{2}$. The oxidase reaction was tested on filter paper moistened with a $1 \%$ $(w / v)$ aqueous solution of $N, N, N^{\prime}, N^{\prime}$-tetramethyl-p-phenylenediamine. The utilization of organic compounds by strain $5-3^{\mathrm{T}}$ was tested in basal medium in which the yeast extract and proteose peptone concentrations were reduced to $0.01 \%$, glucose was omitted and the medium further amended by the addition of $0.5 \mathrm{~g} \mathrm{NH}_{4} \mathrm{Cl} \mathrm{l}^{-1}, 0.05 \mathrm{~g}$ $\mathrm{KH}_{2} \mathrm{PO}_{4} \mathrm{l}^{-1}, 1 \%$ of the respective sugar or alcohol, or $0.1 \%$ of the respective amino acid, with buffering at $\mathrm{pH}$ 7.0. The production of acids from sugars and alcohols was tested in the basal medium supplemented with $5 \mathrm{~g}$ test substrate $1^{-1}$ without buffer; the $\mathrm{pH}$ of the cultures was measured with a $\mathrm{pH}$ electrode. Sensitivity to various antibiotics was determined using the standard disc diffusion assay.

Analysis of the fatty acid methyl esters was carried out by the Analytical Service of the Deutsche Sammlung von Mikroorganismen und Zellkulturen GmbH (Braunschweig, Germany) by means of high-resolution GLC. The fatty acid methyl esters were obtained from fresh wet biomass; the identification and quantification of the fatty acid methyl esters were performed by using Microbial Identification System (MIS) software (MIDI).

Genomic DNA was extracted as described by Marmur (1961). The 16S rRNA genes were amplified with PCRs using primers 16F27 (5'-AGAGTTTGATCMTGGCTCAG$\left.3^{\prime}\right)$ and 16R1525 (5'-AAGGAGGTGWTCCARCC-3'). PCRs were carried out under the conditions described by Saiki et al. (1988). PCR products were purified with a Microcon-100 concentrator (Amicon). Sequences were determined using an ABI PRISM Taq DyeDeoxy DNA sequencer (Applied Biosystems). The primers described by Lane (1991) were used as sequencing primers. Phylogenetic analysis was carried out using MEGA, version 3.1 (Kumar et al., 2004), after multiple alignment of the data by CLUSTAL W, version 1.8 (Thompson et al., 1994). Distances and clustering were determined using the neighbourjoining and maximum-parsimony methods with bootstrap analyses based on 1000 replications.
The genomic DNA G $+\mathrm{C}$ content was determined from the mid-point value $\left(T_{\mathrm{m}}\right)$ of the thermal denaturation profile (Marmur \& Doty, 1962). The $T_{\mathrm{m}}$ was determined by using the graphic method described by Ferragut \& Leclerc (1976) and the DNA G+C content was calculated from this temperature by using the equation of Owen \& Hill (1979).

DNA-DNA hybridization was performed by using the method of Lind \& Ursing (1986) with the modifications of Ziemke et al. (1998).

The cells of strain $5-3^{\mathrm{T}}$ were non-motile, Gram-negative rods approximately $0.6-0.8 \times 0.9-1.5 \mu \mathrm{m}$ in size. The colonies that formed on standard agar medium were cream, smooth, circular, convex and approximately $3 \mathrm{~mm}$ in diameter. Strain $5-3^{\mathrm{T}}$ grew in media containing $5-25 \%$ (w/v) $\mathrm{NaCl}$, with an optimum at $7.5 \%(\mathrm{w} / \mathrm{v}) \mathrm{NaCl}$. Growth occurred at temperatures in the range $30-50{ }^{\circ} \mathrm{C}$, with an optimum at $37-40{ }^{\circ} \mathrm{C}$. The optimal $\mathrm{pH}$ for growth was 7.5 and growth was observed at $\mathrm{pH}$ values of 6.0 to 9.0.

The phenotypic characteristics of strain $5-3^{\mathrm{T}}$ are summarized in the species description and are compared with those of the type strains of related Halomonas species in Table 1.

Strain $5-3^{\mathrm{T}}$ synthesized straight-chain saturated and unsaturated fatty acids in combination with hydroxyl fatty acids. The predominant fatty acids were as follows (\%): $\mathrm{C}_{18: 1} \omega 7 c$ (50.17), $\mathrm{C}_{16: 0}$ (27.04), $\mathrm{C}_{12: 0} \quad 3-\mathrm{OH}$ (5.42), $\mathrm{C}_{19: 0} \omega 8 c$ cyclo (5.39), $\mathrm{C}_{16: 1} \omega 7 c /$ iso- $\mathrm{C}_{15: 0}$ 2-OH (5.08), $\mathrm{C}_{10: 0}(1.64), \mathrm{C}_{12: 0}(1.15)$ and $\mathrm{C}_{18: 0}(1.15)$.

The 16S rRNA gene sequence obtained for strain $5-3^{\mathrm{T}}$ consisted of $1540 \mathrm{bp}$. The fragment analysed contained the 15 signature nucleotides defined for the family Halomonadaceae, as described by Dobson \& Franzmann (1996). It clustered with those for group 1 species of the genus Halomonas, as described by Arahal et al. (2002b), and displayed the highest levels of $16 \mathrm{~S}$ rRNA gene sequence similarity with respect to Halomonas halmophila ATCC $19717^{\mathrm{T}}(99.7 \%)$, Halomonas almeriensis CECT $7050^{\mathrm{T}}$ (98\%), Halomonas eurihalina DSM $5720^{\mathrm{T}}(97.3 \%)$ and Halomonas elongata DSM $2581^{\mathrm{T}}(96.6 \%)$. The phylogenetic tree constructed using the neighbour-joining algorithm is shown in Fig. 1. The phylogenetic tree constructed using the maximum-parsimony algorithm is available as Supplementary Fig. S1 in the online version of this paper. The $\mathrm{G}+\mathrm{C}$ content of the genomic DNA of strain $5-3^{\mathrm{T}}$ was $57.0 \mathrm{~mol} \%\left(T_{\mathrm{m}}\right)$, which is somewhat lower than the value reported for the most closely related Halomonas species (Table 1).

DNA-DNA hybridization experiments between strain 5-3 ${ }^{\mathrm{T}}$ and H. halmophila ATCC $19717^{\mathrm{T}}$, H. eurihalina DSM $5720^{\mathrm{T}}, H$. almeriensis CECT $7050^{\mathrm{T}}$ and H. elongata DSM $2581^{\mathrm{T}}$ revealed levels of relatedness of 50.6, 38.1, 43.5 and $31.4 \%$, respectively. These levels of DNA-DNA hybridization are low enough to justify the classification of strain $5-3^{\mathrm{T}}$ as a novel species within the genus Halomonas, for which we propose the name of Halomonas sabkhae sp. nov. 
Table 1. Differential characteristics of strain $5-3^{\top}$ and closely related Halomonas type strains

Taxa: 1, strain 5-3 $3^{\mathrm{T}} ; 2$, H. halmophila ATCC $19717^{\mathrm{T}} ; 3$, H. almeriensis $\mathrm{M}^{\mathrm{T}} ; 4$, H. eurihalina $\mathrm{F} 9-6^{\mathrm{T}} ; 5$, H. elongata $1 \mathrm{H} 9^{\mathrm{T}}$. Data are from this study and from Dobson et al. (1990), Mata et al. (2002), Martinez-Checa et al. (2005) and Vreeland et al. (1980). +, Positive; -, negative; NR, not reported.

\begin{tabular}{|c|c|c|c|c|c|}
\hline Characteristic & 1 & 2 & 3 & 4 & 5 \\
\hline Cell size $(\mu \mathrm{m})$ & $0.6-0.8 \times 0.9-1.5$ & $0.3-0.6 \times 0.9-1.3$ & $2-2.5 \times 0.75$ & $0.8-1.0 \times 2.0-2.5$ & $\mathrm{NR}$ \\
\hline Motility & - & + & - & - & + \\
\hline Exopolysaccharide & + & - & + & + & - \\
\hline Oxidase & + & + & - & - & - \\
\hline Temperature range $\left({ }^{\circ} \mathrm{C}\right)$ & $30-50$ & $15-45$ & $15-37$ & $4-45$ & $4-45$ \\
\hline $\mathrm{pH}$ range & $6-9$ & $5-10$ & $6-10$ & $5-10$ & $5-9$ \\
\hline \multicolumn{6}{|l|}{ Hydrolysis of: } \\
\hline Aesculin & - & - & - & + & - \\
\hline Gelatin & - & - & - & + & - \\
\hline Starch & - & - & - & - & - \\
\hline Tween 20 & - & + & - & + & - \\
\hline Tween 80 & - & - & - & + & - \\
\hline Tyrosine & + & - & - & + & - \\
\hline ONPG & - & - & - & + & + \\
\hline Urea & - & - & - & + & + \\
\hline Facultatively anaerobic & + & - & - & - & + \\
\hline Reduction of nitrate & + & - & - & + & + \\
\hline \multicolumn{6}{|l|}{ Growth on: } \\
\hline L-Arabinose & - & - & - & + & + \\
\hline D-Fructose & + & + & - & + & + \\
\hline D-Galactose & + & + & - & + & + \\
\hline D-Glucose & + & + & - & + & + \\
\hline Lactose & + & + & - & + & + \\
\hline Maltose & + & + & - & + & + \\
\hline D-Salicin & - & - & - & + & - \\
\hline D-Xylose & - & + & - & + & + \\
\hline Fumarate & - & - & - & + & + \\
\hline Propionate & - & - & - & + & + \\
\hline Succinate & - & - & + & - & + \\
\hline Adonitol & - & - & + & - & + \\
\hline D-Mannitol & - & - & + & - & + \\
\hline L-Alanine & - & + & + & + & + \\
\hline L-Histidine & - & + & + & - & + \\
\hline L-Lysine & - & - & + & - & + \\
\hline Acid from D-glucose & + & + & - & - & + \\
\hline DNA G $+\mathrm{C}$ content $(\mathrm{mol} \%)$ & 57.0 & 63.0 & $59.1-65.7$ & 63.5 & 60.5 \\
\hline
\end{tabular}

\section{Description of Halomonas sabkhae sp. nov.}

Halomonas sabkhae (sab'khae. N.L. gen. n. sabkhae of sabkha, the Arabic name for a salt flat of the type usually found near sand dunes).

Cells are Gram-negative rods $(0.6-0.8 \times 0.9-1.5 \mu \mathrm{m})$ and are non-motile. Colonies are circular, smooth, convex and have cream pigmentation. Produces an exopolysaccharide. Catalase- and oxidase-positive. Moderately halophilic, being capable of growth in 5-25\% (w/v) $\mathrm{NaCl}$ (optimum, $7.5 \%$, w/v). Grows at $\mathrm{pH} 6.0-9.0$, with an optimum at $\mathrm{pH}$ 7.5. The temperature range for growth is $30-50{ }^{\circ} \mathrm{C}$ (optimum, $37-40{ }^{\circ} \mathrm{C}$ ). Utilizes D-glucose, D-galactose, Dfructose, lactose, maltose and sucrose as carbon sources. LArabinose, D-xylose, D-mannose, L-rhamnose, D-salicin, adonitol, dulcitol, glycerol, inositol, D-mannitol, D-sorbitol, acetate, benzoate, citrate, formate, fumarate, lactate, malonate, oxalate, propionate, succinate, L-alanine, Larginine, L-asparagine, L-cysteine, glycine, L-histidine, Lleucine, L-lysine, L-methionine, L-tryptophan and L-tyrosine are not utilized. Acid is produced from D-glucose and D-mannitol, but not from D-galactose, D-fructose, lactose, maltose, sucrose, L-arabinose or L-rhamnose. Grows anaerobically in the presence of nitrate. Does not hydrolyse aesculin, gelatin, starch, Tween 20 or Tween 80 . Negative for lysine decarboxylase, ornithine decarboxylase, urease and $\beta$-galactosidase. Nitrate is reduced to nitrite. Indole, methyl red and Voges-Proskauer tests are negative. Grows on MacConkey agar and hydrolyses tyrosine, but does not produce pigment from tyrosine. Cells are 


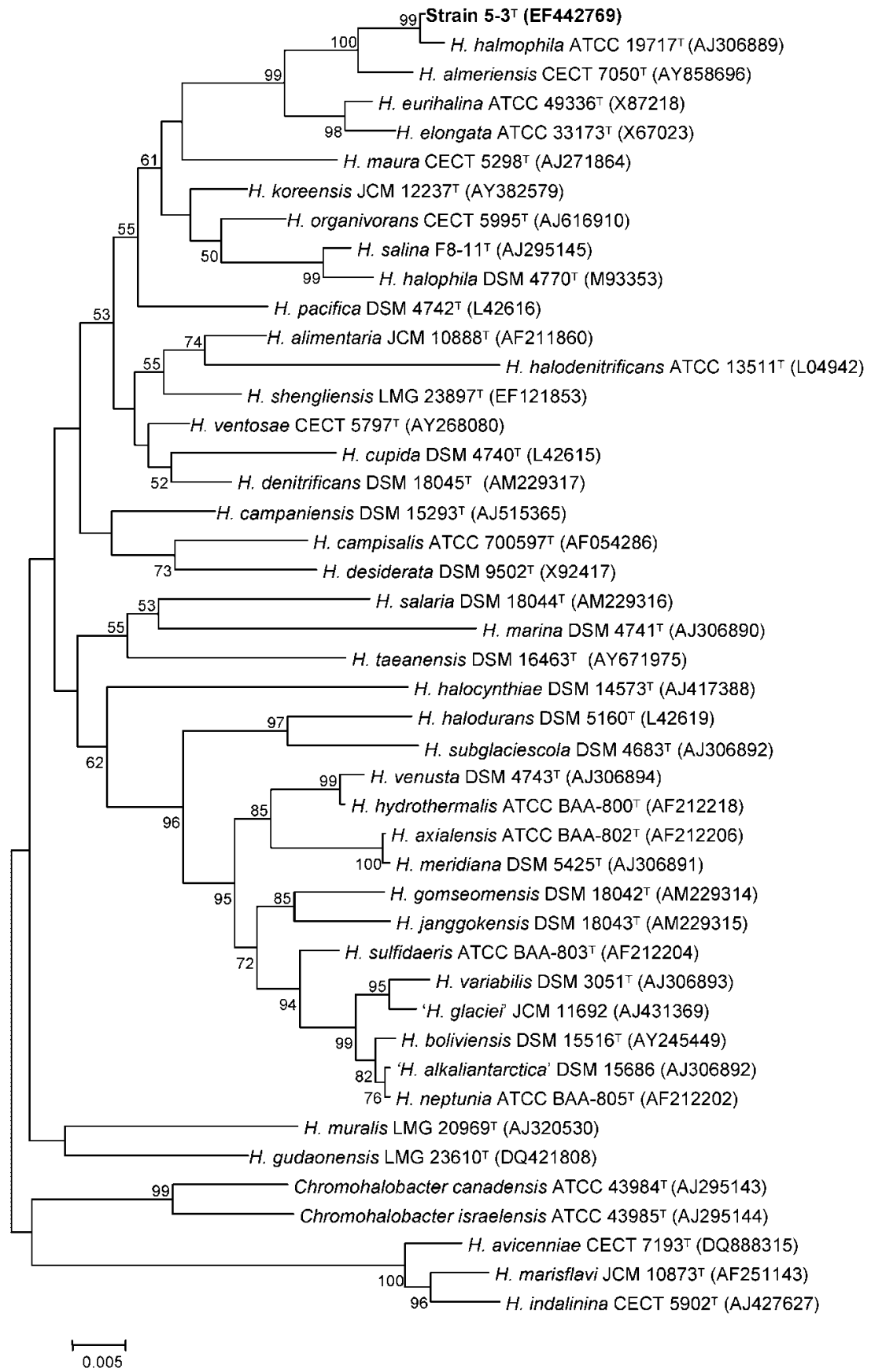

Fig. 1. Neighbour-joining phylogenetic tree, based on 16S rRNA gene sequences, showing the relationships of strain $5-3^{\top}$ and species of the genus Halomonas plus other taxa comprising Gram-negative, halophilic bacteria. Bootstrap percentages (based on 1000 replications) are shown if greater than $50 \%$. Bar, 0.005 substitutions per site. resistant to novobiocin $(30 \mu \mathrm{g})$, bacitracin (10 IU), but sensitive to ampicillin $(10 \mu \mathrm{g})$, kanamycin $(30 \mu \mathrm{g})$, chloramphenicol $(30 \mu \mathrm{g})$, penicillin $\mathrm{G}$ (10 IU), carbenicillin $(100 \mu \mathrm{g})$ and rifampicin $(30 \mu \mathrm{g})$. The major fatty acids are $\mathrm{C}_{12: 0} 3-\mathrm{OH}, \mathrm{C}_{16: 1} \omega 7 c /$ iso- $\mathrm{C}_{15: 0} 2-\mathrm{OH}, \mathrm{C}_{16: 0}, \mathrm{C}_{18: 1} \omega 7 c$ and $\mathrm{C}_{19: 0} \omega 8 c$ cyclo. The DNA G $+\mathrm{C}$ content is $57.0 \mathrm{~mol} \%$ $\left(T_{\mathrm{m}}\right)$.

The type strain, $5-3^{\mathrm{T}}\left(=\mathrm{CECT} 7246^{\mathrm{T}}=\mathrm{DSM} 19122^{\mathrm{T}}=\mathrm{LMG}\right.$ $24084^{\mathrm{T}}$ ), was isolated from brines of Ezzemoul sabkha (Algeria).

\section{Acknowledgements}

We are grateful to Dr Jean Euzéby for etymological advice. This study was supported by grants from the Junta de Andalucía (project CVI190), Spain, and with support from the Algerian Ministry of Education.

\section{References}

Arahal, D. R., Castillo, A. M., Ludwig, W., Schleifer, K. H. \& Ventosa, A. (2002a). Proposal of Cobetia marina gen. nov., comb. nov., within the 
family Halomonadaceae, to include the species Halomonas marina. Syst Appl Microbiol 25, 207-211.

Arahal, D. R., Ludwig, W., Schleifer, K. H. \& Ventosa, A. (2002b). Phylogeny of the family Halomonadaceae based on 23S and 16S rRNA gene sequence analyses. Int J Syst Evol Microbiol 52, 241-249.

Dobson, S. J. \& Franzmann, P. D. (1996). Unification of the genera Deleya (Baumann et al. 1983), Halomonas (Vreeland et al. 1980), and Halovibrio (Fendrich 1988) and the species Paracoccus halodenitrificans (Robinson and Gibbons 1952) into a single genus, Halomonas, and placement of the genus Zymobacter in the family Halomonadaceae. Int J Syst Bacteriol 46, 550-558.

Dobson, S. J., James, S. R., Franzmann, P. D. \& McMeekin, T. A. (1990). Emended description of Halomonas halmophila (NCMB $1971^{\mathrm{T}}$ ). Int J Syst Bacteriol 40, 462-463.

Dussault, H. P. (1955). An improved technique for staining red halophilic bacteria. J Bacteriol 70, 484-485.

Fendrich, C. (1988). Halovibrio variabilis gen. nov. sp. nov., Pseudomonas halophila sp. nov. and a new halophilic aerobic coccoid Eubacterium from Great Salt Lake, Utah. Syst Appl Microbiol 11, 36-43.

Ferragut, C. \& Leclerc, H. (1976). Étude comparative des méthodes de détermination du $T_{\mathrm{m}}$ de l'ADN bactérien. Ann Microbiol (Paris) 127, 223-235.

Franzmann, P. D., Burton, H. R. \& McMeekin, T. A. (1987). Halomonas subglaciescola sp. nov., a new species of halotolerant bacteria isolated from Antarctica. Int J Syst Bacteriol 37, 27-34.

Franzmann, P. D., Wehmeyer, U. \& Stackebrandt, E. (1988). Halomonadaceae fam. nov., a new family of the class Proteobacteria to accommodate the genera Halomonas and Deleya. Syst Appl Microbiol 11, 16-19.

Garriga, M., Ehrmann, M. A., Arnau, J., Hugas, M. \& Vogel, R. F. (1998). Carnimonas nigrificans gen. nov., sp. nov., a bacterial causative agent for black spot formation on cured meat products. Int J Syst Bacteriol 48, 677-686.

Kaye, J. Z., Márquez, M. C., Ventosa, A. \& Barros, J. A. (2004). Halomonas neptunia sp. nov., Halomonas axialensis sp. nov. and Halomonas hydrothermalis sp. nov.: halophilic bacteria isolated from deep-sea hydrothermal-vent environments. Int J Syst Evol Microbiol 54, 499-511.

Kharroub, K., Aguilera, M., Quesada, T., Morillo, J. M., RamosCormenzana, A., Boulahrouf, A. \& Monteoliva-Sanchez, M. (2006). Salicola salis sp. nov., an extremely halophilic bacterium isolated from Ezzemoul sabkha in Algeria. Int J Syst Evol Microbiol 56, 2647-2652.

Kumar, S., Tamura, K. \& Nei, M. (2004). MEGA3: integrated software for molecular evolutionary genetics analysis and sequence alignment. Brief Bioinform 5, 150-163.

Lane, D. J. (1991). 16S/23S rRNA sequencing. In Nucleic Acid Techniques in Bacterial Systematics, pp. 115-175. Edited by E. Stackebrandt \& M. Goodfellow. Chichester: Wiley.

Larpent, J.-P. \& Larpent-Gourgaud, M. (1985). Manuel Pratique de Microbiologie. Paris: Hermann.

Lind, E. \& Ursing, J. (1986). Clinical strains of Enterobacter agglomerans (synonyms Erwinia herbicola, Erwinia milletiae) identified by DNA-DNA hybridization. Acta Pathol Microbiol Immunol Scand $[B]$ 94, 205-213.

Marmur, J. (1961). A procedure for the isolation of deoxyribonucleic acid from microorganisms. J Mol Biol 3, 208-218.

Marmur, J. \& Doty, P. (1962). Determination of the base composition of deoxyribonucleic acid from its thermal denaturation temperature. J Mol Biol 5, 109-118.

Martinez-Cánovas, M. J., Béjar, V., Martinez-Checa, F. \& Quesada, E. (2004). Halomonas anticariensis sp. nov., from Fuente de Piedra, a saline-wetland wildfowl reserve in Málga, southern Spain. Int J Syst Evol Microbiol 54, 1329-1332.

Martinez-Checa, F., Béjar, V., Martinez-Cánovas, J., Liama, I. \& Quesada, E. (2005). Halomonas almeriensis sp. nov., a moderately halophilic, exopolysaccharide-producing bacterium from Cabo de Gata, Almeria, south-east Spain. Int J Syst Evol Microbiol 55, 2007-2011.

Mata, J. A., Martinez-Cánovas, J., Quesada, E. \& Béjar, V. (2002). A detailed phenotypic characterization of the type strains of Halomonas species. Syst Appl Microbiol 25, 360-375.

Okamoto, T., Taguchi, H., Nakamura, K., Ikenaga, H., Kuraishi, H. \& Yamasato, K. (1993). Zymobacter palmae gen. nov., sp. nov., a new ethanol-fermenting peritrichous bacterium isolated from palm sap. Arch Microbiol 160, 333-337.

Oren, A., Gurevich, P., Gemmel, R. T. \& Teske, A. (1995). Halobaculum gomorrense gen. nov., sp. nov., a novel extremely halophilic archaeon from the Dead Sea. Int J Syst Bacteriol 45, 747-754.

Owen, R. J. \& Hill, L. R. (1979). The estimation of base compositions, base pairing and genome sizes of bacterial deoxyribonucleic acids. In Identification Methods for Microbiologists (Society for Applied Bacteriology Technical Series no. 14), 2nd edn, pp. 277-296. Edited by F. A. Skinner \& D. W. Lovelock. London: Academic Press.

Poli, A., Esposito, E., Pierangelo, O., Lama, L., Giordano, A., de Appolonia, F., Nicolaus, B. \& Gambacorta, A. (2007). Halomonas alkaliantarctica sp. nov., isolated from saline lake Cape Russell in Antarctica, an alkalophilic moderately halophilic, exopolysaccharideproducing bacterium. Syst Appl Microbiol 30, 31-38.

Quillaguamán, J., Hatti-Kaul, R., Mattiasson, B., Alvarez, M. T. \& Delgado, O. (2004). Halomonas boliviensis sp. nov., an alkalitolerant, moderate halophile isolated from soil around a Bolivian hypersaline lake. Int J Syst Evol Microbiol 54, 721-725.

Reddy, G. S. N., Raghavan, P. U. M., Sarita, N. B., Prakash, J. S. S., Nagesh, N., Delille, D. \& Shivaji, S. (2003). Halomonas glaciei sp. nov. isolated from fast ice of Adelie Land, Antarctica. Extremophiles 7, 55-61.

Rodriguez-Valera, F., Ruiz-Berraquero, F. \& Ramos-Cormenzana, A. (1981). Characteristics of the heterotrophic bacterial populations in hypersaline environments of different salt concentrations. Microb Ecol 7, 235-243.

Saiki, R. K., Gelfand, D. H., Stoffel, S., Scharf, S. J., Higuchi, R., Horn, G. T., Mullis, K. B. \& Erlich, H. A. (1988). Primer-directed enzymatic amplification of DNA with a thermostable DNA polymerase. Science 239, 487-491.

Smibert, R. M. \& Krieg, N. R. (1981). General Characterization. In Manual of Methods for General Bacteriology, pp. 409-443. Edited by P. Gerhardt, R. G. E. Murray, R. N. Costilow, E. D. Nester, W. A. Wood, N. R. Krieg \& G. B. Phillips. Washington, DC: American Society for Microbiology.

Subov, N. N. (1931). Oceanographical Tables. Moscow: USSR Oceanographic Institute Hydrometeorological Commission.

Thompson, J. D., Higgins, D. G. \& Gibson, T. J. (1994). CLUSTAL W: improving the sensitivity of progressive multiple sequence alignment through sequence weighting, position-specific gap penalties and weight matrix choice. Nucleic Acids Res 22, 4673-4680.

Ventosa, A., Gutierrez, M. C., Garcia, M. T. \& Ruiz-Berraquero, F. (1989). Classification of "Chromobacterium marismortui" in a new genus, Chromohalobacter gen. nov., as Chromohalobacter marismortui comb. nov., nom. rev. Int J Syst Bacteriol 39, 382-386.

Vreeland, R. H., Litchfield, C. D., Martín, E. L. \& Elliot, E. (1980). Halomonas elongata, a new genus and species of extremely salttolerant bacteria. Int J Syst Bacteriol 30, 486-495.

Ziemke, F., Höfle, M. G., Lalucat, J. \& Rosselló-Mora, R. (1998). Reclassification of Shewanella putrefaciens Owen's genomic group II as Shewanella baltica sp. nov. Int J Syst Bacteriol 48, 179-186. 